\title{
Research on the Development of Entrepreneurial Culture in Marx's View*
}

\author{
He Liu \\ Baicheng Normal University \\ Baicheng, China
}

\begin{abstract}
Entrepreneurial culture, which contains a wealth of philosophy, determines its needs to the guidance of philosophy. Marxism philosophy, as the essence of the spirit of the times, plays a significant role in guiding the construction of entrepreneurial culture. The basic features of the construction of entrepreneurial culture in the Marx's view include affinity to the people, nationality, science and openness.
\end{abstract}

Keywords-Marxism; construction of entrepreneurial culture; philosophy view

\section{INTRODUCTION}

As an objective phenomenon, entrepreneurial culture comes into being along with entrepreneurial practice. With entrepreneurial practice, there will be entrepreneurial culture. The entrepreneurial practice process of entrepreneurs can also be said to be the melting and casting process of a culture, that is, the formation process of entrepreneurial culture. The theory of entrepreneurial culture, which comes into being with entrepreneurial practice, must be based on certain theories and guided by certain theories. Marxist philosophy as the essence of the spirit of the times and the soul of civilization can best manifest the trend and direction of the development of the times. Therefore, to observe and reflect on the construction of entrepreneurial culture from the perspective of Marxist philosophy is an organic fit between the spirit of the times and the development of culture.

\section{ANALYSIS OF THE PHILOSOPHICAL THOUGHTS CONTAINED IN ENTREPRENEURIAL CULTURE}

\section{A. The People Oriented Concept}

Entrepreneurial culture not only regards entrepreneurial practice as a process of transforming the world and creating wealth, but also regards entrepreneurial culture as a process of continuous improvement of people's spiritual life and cultural world. In this process, people are at the center of all production activities and life activities, and entrepreneurial culture must reflect the people-oriented concept, "everything is for people". Therefore, entrepreneurial practices and entrepreneurial culture exist and come into being according

*Fund: This paper is the phased achievement of the 13th Five-year Social Science Research Project of the Jilin Provincial Department of Education; Research on the development outlook of contemporary entrepreneurial culture; Research on the philosophical implication of contemporary entrepreneurial culture. to the needs of entrepreneurial subjects. One must respect, liberate, rely on, shape and serve people in their entrepreneurial practices. Respecting for people means respecting for entrepreneurs' class value, social value, personality value, independent personality, needs, creation of personality and rights; to liberate people means to break through all kinds of mechanisms and systems that restrict the full development of entrepreneurs' potential and ability. Relying on people is to fully mobilize people's enthusiasm, initiative and creativity to design, manage, organize, coordinate and operate the entrepreneurial practice process, and accumulate entrepreneurial culture in it; shaping people means shaping entrepreneurs into real subjects of rights and responsibilities. Respecting people, liberating people, relying on people and shaping people are all for people in the end.

\section{B. The Scientific Outlook on Development}

The scientific outlook on development reveals the essence and connotation of development and is the fundamental viewpoint guiding people's practice and cognition. The scientific outlook on development emphasizes the adherence to economic construction as the center, which embodies the historical materialism's view that productive forces are the basis of human social development. The scientific outlook on development adheres to comprehensive and coordinated development, which embodies the basic principle of materialist dialectics about universal connection and dialectical unity among things. The scientific development view insists on the sustainable development, embodies the dialectical materialism about the relationship between man and nature. Scientific concept of development focuses on rich connotation development, innovation and development, pioneering and development, the crack development difficult problem, in the development path and development mode, development strategy, development power requirements, the purpose of development and put forward a series of new ideas and methods, provides a set of system theory for entrepreneurial activities. To witness entrepreneurial culture with the concept of scientific development is to take the scientific outlook on development into entrepreneurial culture, combined with the specific business practices, guide the construction of entrepreneurial culture, by the scientific development view to deal with the natural, social and business subject (people), the relationship between nature, society and business subject (people) of scientific development and harmonious development. 


\section{The Humanistic Spirit}

An excellent entrepreneurial culture must be produced and developed on the basis of integrating certain essence of humanistic spirit. Humanistic spirit is a kind of inquiry and concern for human survival and destiny in the mutual relations between human and nature, human and society, human and science and technology. It is the search for the ideal, relationship and criterion of how people become people, what kind of people they become, and the establishment of which way of life is more in line with people's needs. It is also the pursuit and confirmation of the nation and people's survival significance, value and spirit. Humanistic spirit is the support of people's spiritual home and the ultimate pursuit of human freedom and human liberation. The fierce competition among countries in the 21 st century is not only reflected in the competition of science and technology and economic strength, but also in the competition of national cultural deposits, national spirit and spiritual civilization. As a form of culture, entrepreneurial culture must embody certain humanistic spirit and humanistic care. The humanistic spirit in the entrepreneurial culture is embodied in the fact that the entrepreneurial subjects should realize their own social responsibilities, form an atmosphere conducive to their own personality and personality improvement, and shape themselves into all-round people in the broadest sense. From the perspective of humanistic spirit, entrepreneurial culture and entrepreneurial practice should be embodied in two kinds of harmony. The first is the harmony between entrepreneurial practice and natural ecosystem. The second is the harmony between the entrepreneurial subjects, forming the concept of symbiosis, coexistence and sharing between the entrepreneurial subjects.

\section{The GuIdING Role OF MARXIST PhILOSOPHY IN THE CONSTRUCTION OF ENTREPRENEURIAL CULTURE}

\section{A. Practical Guidance for Entrepreneurial Culture}

Entrepreneurial practice is the historical activity of society. Entrepreneurial practice is a social practice at the very beginning, but also a historical development of practice. People always carry out entrepreneurial practice activities in a certain social relationship, although entrepreneurial practice activities can be shown as individual or individual activities, but individuals always rely on the power of the society to naturally develop relations and engage in entrepreneurial practice activities. Entrepreneurial practice activities are always carried out under specific historical conditions and always subject to specific historical conditions, that is, the object, scope, scale and mode of entrepreneurial practice activities are all subject to historical conditions.

\section{B. Guidance of Innovation to Entrepreneurial Culture}

The guidance of innovation to entrepreneurial culture is mainly reflected in the fact that entrepreneurs should establish a firm sense of innovation and stimulate their own innovation ability to the greatest extent in entrepreneurial practices. Innovation consciousness is the level and degree of people's cognition of the value and importance of innovation and the attitude to innovation formed by it. Innovation consciousness of entrepreneurs is very important for entrepreneurial practice. Generally speaking, innovation consciousness of entrepreneurs mainly includes innovation intention, innovation desire and entrepreneurial motivation. The strong or weak innovation consciousness of entrepreneurs directly affects the development of entrepreneurial practice activities and the expected results of entrepreneurial practice activities. In addition to a firm sense of innovation, entrepreneurs should also have a strong ability of innovation. In the process of starting a business, entrepreneurs can stimulate their innovation ability to the greatest extent, so that entrepreneurial practice activities can not only be carried out smoothly, but also realize the purpose of entrepreneurial practice to the greatest extent.

\section{A Guide to Entrepreneurial Culture That Keeps Pace with the Times}

As the main body of entrepreneurship, entrepreneurs should always grasp the pulse of the development of the times and timely adjust entrepreneurial practices according to the actual situation. The guidance of keeping pace with the times to entrepreneurship culture reveals such a truth that entrepreneurship theory and the entrepreneurship routes, programs, policies and so on formulated under its guidance all belong to the category of knowledge and consciousness. Therefore, they must develop continuously with the development of entrepreneurship practice and constantly enrich with the changes of the times. The theory of entrepreneurial culture summarized and formed by entrepreneurs in the process of entrepreneurial practice does not exhaust the understanding of entrepreneurial theory. These understandings only provide scientific means and methods for entrepreneurial subjects to explore entrepreneurial theories in entrepreneurial practices. Therefore, just as entrepreneurial practice is never ending, the theory of entrepreneurial culture must constantly enrich itself from practice, and constantly absorb all the beneficial results created by human beings to improve themselves.

\section{THE BASIC CHARACTERISTICS OF ENTREPRENEURIAL CULTURE CONSTRUCTION FROM THE PERSPECTIVE OF MARXIST PHILOSOPHY}

\section{A. The Popularity of Entrepreneurial Culture Construction}

People are the main body of entrepreneurial practice, and entrepreneurial culture is formed by the masses of people in the long-term entrepreneurial practice. Entrepreneurial culture fundamentally represents the fundamental interests of the masses. Entrepreneurial culture comes from the masses of the people, serves the masses of the people and represents the aspirations of the masses of the people, in order to meet the growing cultural needs of the masses of the people to serve. The broad masses of the people are not only the main body of entrepreneurial practice, but also the main body of entrepreneurial culture construction. Whether the broad masses of people participate in, support or support is the key to ensure the success of the construction of entrepreneurial 
culture. The construction of entrepreneurial culture must reflect the characteristics of the people and the masses. It must proceed from the fundamental interests of the broad masses of the people and reflect the requirements of the broadest masses of the people. This is the basic requirement and fundamental starting point for the existence and development of any culture. In the construction of entrepreneurial culture, if it leaves the masses, it will lose the source and power of development and lose the goal and direction of innovative development.

\section{B. The Nationality of Entrepreneurial Culture Construction}

Entrepreneurial culture is created by the masses through entrepreneurial practices. Entrepreneurial culture exists in the whole social group as soon as it comes into being, and can be continuously inherited and developed through people's accumulation and transmission from generation to generation. The building of entrepreneurial culture must be deeply rooted in the fertile soil of China, must embody the essence of the Chinese national culture, and must have a distinctive national style and Chinese style. If the construction of entrepreneurial culture cannot be integrated into the culture of the Chinese nation and cannot be widely recognized by the Chinese nation, it cannot become one of the most extensive cultural forms of the Chinese nation. Therefore, it is necessary to combine the positive content of the entrepreneurial culture construction with the tradition and demeanor of the Chinese nation, and combine the entrepreneurial culture construction with the manifestation of the traditional culture of the Chinese nation so that the construction of entrepreneurial culture can be fresh and lively for the broad masses of the Chinese people's favorite style and style.

\section{The Scientific Nature of Entrepreneurial Culture Construction}

In order to be scientific, a culture must objectively reflect people's true knowledge of the relationship between man and nature, man and society and man and self. The requirements in the process of construction of entrepreneurial culture, must adhere to the guiding position of Marxist philosophy, to correctly handle the guiding position of Marxist philosophy and other theories; the relationship between should be based on national revitalization and prosperity of historiography and focus on promoting the ascension of the Chinese national cohesion and creativity, to insist the direction of socialist advanced culture, stimulate the cultural creativity of the whole nation, improve the national cultural soft power, focusing on the development trend of world culture and direction, from the law and internal logic of cultural development, constantly to realize the scientific nature of the entrepreneurial culture construction requirements.

\section{CONCLUSION}

In short, the rise and development of entrepreneurial culture is an inevitable product of the development of human society. Entrepreneurial culture is an important carrier of socialist culture with Chinese characteristics, and the construction of entrepreneurial culture is an important part of the construction of socialist culture with Chinese characteristics. Therefore, it is necessary to improve the selfconsciousness of entrepreneurial culture construction, strengthen the theoretical awareness and practical awareness of entrepreneurial culture construction under the guidance of the basic viewpoints and methods of Marxist philosophy, strive to promote the great development and prosperity of entrepreneurial culture, and constantly improve the soft power of socialist culture with Chinese characteristics.

\section{REFERENCES}

[1] Lee Roy Beach. Making the Right Decision: Organizational Culture. Vision, and Planning, Prentice Hall, 1993.

[2] March J G. Exploration and exploitation in organizational learning [J] Organization Science, 1991(2).

[3] Gareth Morgan. Creative Organization Theory: A Resource Book, SAGE Publications Ltd. 1989.

[4] Peter Drucker. Innovation and Entrepreneurship: Practice and Principles, Harper\&Row, 1985.

[5] Tony Proctor. The Essence of Manageme: Creativity. Prentice Hall Europe, 1995. 